\title{
Upaya Pencegahan Anak dari Pengaruh Minuman Keras Dihubungkan dengan Undang- Undang Nomor 35 Tahun 2014 Tentang Perlindungan Anak: Tinjauan
}

\author{
Dudu Duswara M, Dani Durahman \\ Dosen Universitas Lalangbuana
}

\begin{abstract}
The current rise in alcoholic trade, in small roadside stalls, even among them has been openly trading alcohol. This results in the ease with which people get liquor. Including the alcoholic trade which is not accompanied by knowledge of the type of alcoholic beverage itself. Many of them do not understand the type of alcohol they can drink or not. Circulation of liquor at this time has not been handled properly, due to the lack of law enforcement against liquor sellers, so that with the easy sale of liquor that is still running it results in children who participate in becoming consumers and consuming liquor so that it has a negative impact on child growth and development. The number of alcoholic parties is certainly not just happening, the ease of people getting liquor makes some people easily drink alcohol. If we look at a number of events, this alcoholic party is carried out by a group of elderly people to high school children who are only a dozen years old. This happens because people can buy liquor easily at convenience stores. The ease of access to liquor is then one of the factors supporting the many alcoholic party events in the community. Another supporting factor from the rise of alcoholic parties in the Cigending Village community is the circulation of illegal alcohol in the community. One of the behaviors of children who reach adolescence is to show their true identity to friends or the environment, with environmental behavior that is not good and is not well cared for by the family can be excessive. In general, teenagers want to be recognized and get special treatment. Negative relationships that influence the use of liquor among teenagers. Liquor can damage the development of child development so there is a need for efforts to protect children from the bad influence of hard miniman as an effort to implement Law No. 35 of 2014 concerning Child Protection. The task of controlling this is in accordance with what is mandated by the Food Law, where the National Police has the right and obligation to control illegal alcoholic drinks without permission in accordance with applicable laws and regulations. Efforts to control illegal alcoholic beverages will greatly affect the decline in the incidence of alcoholic drinks because according to several events, people who carry out alcoholic drinks are usually from the lower middle class
\end{abstract}

Keywords: Efforts to prevent the adverse effects of liquor on children

\section{PENDAHULUAN}

Masyarakat tidak dapat didefinisikan secara singkat dan sederhana sebab "masyarakat" memiliki arti yang berbeda-beda untuk tiap-tiap orang. Unit terkecil dari sebuah masyarakat adalah keluarga (keluarga inti dan keluarga besar), lingkungan tetangga, famili/warga dan lembaga-lembaga pendukungnya.Setiap masyarakat memiliki karakteristik yang berbeda, antara lain budaya, nilai dan masalah yang beraneka ragam, terutama di daerah perkotaan. Masyarakat juga tidak hanya terdiri dari pemerintah daerah setempat tetapi ada juga lembaga-lembaga, termasuk juga penduduk di sebuah lingkungan, disuatu daerah tertentu.

Penyakit Masyarakat selalu menjadi topik utama dalam surat kabar,berdasarkanberita-berita di surat kabar, sasaran penyaki tmasyaraka tbukan saja anakanak muda tap ijuga orang dewasa dari berbagai lapisan masyaralkat, termasuk pula pegawai negri dan polisi. Penyakit masyarakat merupakan perilaku menyimpang yang terjadi dalam sosial masyarakat. Bentuk-bentuk penyimpangan tersebut, apabila terus berkembang akan menyebabkan timbulnya penyakit social dalam masyarakat. Dengan kata lain, penyakit social adalah bentuk penyimpangan terhadap norma masyarakat yang dilakukan secara terus-menerus. Sementara itu, bentukbentuk penyakit sosial pun bermacam-macam. Beberapa penyakit sosial yang bias ditemukan di masyarakat salah satunya minuman keras.

Minumankeras adala hminuman yang memiliki kandungan alcohol lebih dari 5 persen. Keberadaan miras di Indonesia sangat dibatasi oleh aturan pemerintah. Orang-orang yang menyalahgunakan miras akan dikenai sanksi. Adapun yang dimaksud penyalahgunaan di sini adalah suatu bentuk pemakaian yang tidak sesuai dengan ambang batas kesehatan. Artinya, minuman keras boleh digunakan sejauh hanya untuk maksud pengobatan atau kesehatan di bawah pengawasan dokter atau ahlinya. Di beberapa daerah di Indonesia, terdapat jamu atau minuman tradisional yang dapat digolongkan sebagai minuman keras. Sebenarnya, jika tidak digunakan secara berlebihan, jamu atau minuman tradisional yang dapat digolongkan sebagai minuman keras tersebut, dapat bermanfaat bagitubuh. Namun, sangat disayangkan jika jamu atau minuman tradisional tersebut, dikonsumsi secara berlebihan atau sengaja digunakan untuk mabukmabukan. Para peminum minuman keras dapat dianggap sebagai penyakit masyarakat.

Peredaran minuman keras saatini belum dapat tertangani denganbaik, dikarenakan lemahnya penegakkan hukum terhadap penjual minuman keras, sehingga dengan adanya penjualan secaramu dahminuman keras yang masih berjalan berakibat adanya anak yang turut mengkonsumsi minuman keras sehingga berakibat buruk terhadap tumbuh kembang anak dan bertentangan dengan Undang-Undang Nomor 34 Tahun2014 tentang Perlindungan Anak dimana setiap anak berhak mendapatkan penghidupan yang layak.

\section{Tinjauan Pustaka Minuman Keras}

Minuman keras adalah minuman yang memiliki kandungan alkohol lebih dari 5 persen. Keberadaan miras di Indonesia sangat dibatasi oleh aturan pemerintah. Orang-orang yang menyalahgunakan miras akan dikenai sanksi. Adapun yang dimaksud penyalahgunaan di sini adalah suatu bentuk pemakaian 
yang tidak sesuai dengan ambang batas kesehatan. Artinya, pada dasarnya minuman keras boleh digunakan sejauh hanya untuk maksud pengobatan atau kesehatan di bawah pengawasan dokter atau ahlinya. Di beberapa daerah di Indonesia, terdapat jamu atau minuman tradisional yang dapat digolongkan sebagai minuman keras. Sebenarnya, jika tidak digunakan secara berlebihan, jamu atau minuman tradisional yang dapat digolongkan sebagai minuman keras tersebut, dapat bermanfaat bagi tubuh. Namun, sangat disayangkan jika jamu atau minuman tradisional tersebut, dikonsumsi secara berlebihan atau sengaja digunakan untuk mabukmabukan. Para pemabuk minuman keras dapat dianggap sebagai penyakit masyarakat. Para pemabuk biasanya sudah kehilangan rasa malunya, tindakannya tidak terkontrol, dan sering kali melakukan hal-hal yang melanggar aturan masyarakat atau aturan hukum. Minuman keras juga berbahaya jika dikonsumsi saat mengemudi, karena dapat merusak konsentrasi sehingga dapat menimbulkan kecelakaan. Pada pemakaian jangka panjang, tidak jarang para pemabuk minuman keras meninggal dunia karena organ lambung atau hatinya rusak akibat efek samping alkohol yang dikonsumsinya.

Kejahatan adalah tingkah laku yang melanggar hukum dan melanggar norma-norma sosial, sehingga masyarakat menentangnya. Secara yuridis formal, kejahatan adalah bentuk tingkah laku yang bertentangan dengan moral kemanusiaan (amoral), merugikan masyarakat, sifatnya asosiatif, dan melanggar hukum/undang-undang pidana. Tindak kejahatan bisa dilakukan oleh siapa pun baik wanita maupun pria, dapat berlangsung pada usia anak, dewasa, maupun usia lanjut. Tindak kejahatan pada umumnya terjadi pada masyarakat yang mengalami perubahan kebudayaan yang cepat, yang tidak dapat diikuti oleh semua anggota masyarakat, sehingga tidak terjadi penyesuaian yang sempurna. Selain itu, tindak kejahatan bisa muncul karena adanya tekanan mental atau kepincangan sosial. Oleh karena itu, tindak kejahatan (kriminalitas) sering terjadi pada masyarakat yang dinamis seperti di perkotaan. Tindak kejahatan (kriminalitas) mencakup pembunuhan, penjambretan, perampokan, korupsi, dan lain-lain.

\section{Pengertian dan Hak Anak Pengertian Anak}

Menurut ketentuan Pasal 47 ayat (1) dan Pasal 50 ayat (1) Undang-Undang No. 1 tahun 1974 tentang Perkawinan batasan untuk disebut anak adalah belum mencapai umur 18 (delapan belas) tahun atau belum pernah melangsungkan perkawinan.

Berdasarkan Undang-undang Hukum Pidana Pasal 45 batasan anak adalah orang yang berumur dibawah 16 (enam belas) tahun. Terhadap hal ini baik secara teoritik dan praktik maka apabila anak melakukan tindak pidana hakim dapat menentukan anak tersebut dikembalikan kepada orang tuanya, wali atau pemeliharanya tanpa panjatuhan pidana sebagai anak negara atau juga dapat dijatuhi pidana. ${ }^{1}$

1 Lilik Mulyadi, Pengadilan Anak di Indonesia Teori, Praktik dan Permasalahannya, Mandar Maju, Bandung 2005, hlm. 6
Ketentuan batasan umur menurut Pasal 171 Undang-Undang No. 8 tahun 1981 tentang Kitab Undang-undang Hukum Acara Pidana umur anak di sidang pengadilan yang boleh diperiksa tanpa sumpah digunakan batasan umur di bawah 15 (lima belas) tahun dan belum pernah kawin.

Ketentuan Pasal 1 angka 8 huruf a, b dan c Undang-Undang No. 12 tahun 1995 tentang Lembaga Pemasyarakatan bahwa anak didik pemasyarakatan baik anak pidana, anak Negara dan anak sipil untuk dapat didik di Lapas Anak adalah paling lama sampai berusia 18 (delapan belas) tahun

Sedangkan menurut Pasal 1 angka (5) UndangUndang Nomor 39 Tahun 1999 Tentang Hak Asasi Manusia, pengertian anak adalah : "Anak adalah setiap manusia yang berusia di bawah 18 (delapan belas) Tahun dan belum menikah, termasuk anak yang masih dalam kandungan apabila hal tersebut adalah demi kepentingannya"

Pasal 1 angka (1) Undang-Undang Nomor 11 Tahun 2012 Tentang Sistem Peradilan Anak, pengertian anak yaitu: "Anak adalah orang yang dalam perkara Anak Nakal telah mencapai umur 8 (delapan) Tahun tetapi belum mencapai umur 18 (delapan belas) Tahun dan belum pernah kawin". Bahwa menurut UndangUndang Pengadilan Anak, bagi seorang anak yang belum mencapai usia 8 (delapan) tahun itu belum dapat mempertanggungjawabkan perbuatannya walaupun perbuatan tersebut merupakan tindak pidana.

Menurut Pasal 1 ayat (1) Undang-Undang No 23 tahun 2002 tentang Perlindungan Anak, definisi anak adalah seseorang yang belum berusia 18 tahun, termasuk yang masih ada dalam kandungan. Sedangkan menurut undang-undang pengadilan anak, anak adalah orang yang dalam perkara pidana telah mencapai delapan tahun tetapi belum mencapai umur 18 tahun dan belum pernah kawin. ${ }^{2}$

Setiap anak berhak untuk diasuh oleh orang tuanya sendiri, kecuali jika ada alasan atau aturan hukum yang sah menunjukkan bahwa pemisahan itu adalah demi kepentingan terbaik bagi anak dan merupakan pertimbangan terakhir.(Pasal 14 UndangUndang No. 35 Tahun 2014). Penangkapan, penahanan, atau tindak pidana penjara anak hanya dilakukan apabila sesuai dengan hukum yang berlaku dan hanya dapat dilakukan sebagai upaya terakhir. Pasal 16 ayat (3) Undang-Undang 35 Tahun 2014 tentang Perlindungan Anak.

Pengertian anak pada Pasal 1 angka 1 UndangUndang No. 11 tahun 2012 tentang Sistem Peradilan Anak adalah seseorang yang terlibat dalam perkara anak nakal. Yang dimaksud anak nakal dalam Pasal 1 angka 2 mempunyai dua pengertian, yaitu: ${ }^{3}$

\section{Anak yang melakukan tindak pidana}

Perbuatan yang dilakukan anak tidak terbatas pada perbuatan-perbuatan yang melanggar peraturan KUHP saja melainkan juga melanggar peraturan-

\footnotetext{
2 Arief Gosita, Pengembangan Hak-Hak Anak Indonesia Dalam Proses Peradilan Pidana. Rajawali. Jakarta 1986.hlm.5 ${ }^{3} /$ bid. hlm.27
} 
peraturan di luar $\mathrm{KUHP}^{4}$ misalnya ketentuan pidana dalam Undang-undang Narkotika, Undang-undang Hak Cipta, Undang-undang Pengelolaan Lingkungan Hidup, dan sebagainya.

\section{Anak yang melakukan perbuatan yang dinyatakan terlarang bagi anak}

Perbuatan yang terlarang bagi anak adalah baik menurut peraturan perundang-undangan maupun peraturan hukum lain yang hidup dan berlaku dalam masyarakat. Dalam segi usia pengenaan tindakan terutama bagi anak yang masih berumur 8 (delapan) tahun sampai 12 (dua belas) tahun. Terhadap anak yang telah melampaui umur di atas 12 (dua belas) sampai 18 (delapan belas) tahun dijatuhkan pidana. Hal itu di lakukan mengingat pertumbuhan dan perkembangan fisik, mental, dan sosial anak.

Anak yang melakukan tindak pidana ini juga dikenai sanksi pidana. Berbicara mengenai pemidanaan terhadap anak sering menimbulkan perdebatan yang ramai dan panjang, karena masalah ini mempunyai konsekuensi yang sangat luas baik menyangkut diri pelaku maupun masyarakat. Pemidanaan merupakan unsur dari hukum pidana, dimana pemidanaan itu mempunyai akibat negatif bagi yang dikenai pidana, sehingga dalam penjatuhan pidana terhadap anak hakim harus menggunakan dasar pertimbangan yang rasional sehingga dapat dipertanggungjawabkan. ${ }^{5}$ Bagi sebagian orang, menjatuhkan pidana bagi anak dianggap tidak bijak, akan tetapi ada sebagian yang beranggapan bahwa pemidanaan terhadap anak tetap penting dilakukan, agar sikap buruk anak tidak terus menjadi permanen sampai ia dewasa.

Bagir Manan berpendapat bahwa anak-anak di lapangan hukum pidana diperlakukan sebagai "orang dewasa kecil", sehingga seluruh proses perkaranya kecuali di Lembaga Pemasyarakatan dilakukan sama dengan perkara orang dewasa. ${ }^{6}$ Perlakuan yang berbeda hanya pada waktu pemeriksaan di sidang pengadilan, sidang untuk perkara anak dilakukan secara tertutup (Pasal 153 ayat (3) KUHAP) dan petugasnya (hakim dan jaksa) tidak memakai toga. Semua itu terkait dengan kepentingan fisik, mental dan sosial anak yang bersangkutan.Pemeriksaan perkara anak dilakukan secara tertutup sesuai dengan ketentuan Pasal 42 ayat (3) Undang-Undang Nomor 11 tahun 2012 tentang Sistem Peradilan Anak (selanjutnya disebut UndangUndang Pengadilan Anak) menyatakan bahwa proses penyidikan anak wajib dirahasiakan. Oleh karena itu semua tindakan penyidik dalam rangka penyidikan anak wajib dirahasiakan, dan tanpa ada kecualinya. ${ }^{7}$

Penilaian hakim pendidikan dan pembinaan terhadap anak nakal tidak dapat lagi dilakukan di lingkungan keluarga Pasal 24 ayat (1) huruf b UndangUndang No. 11 tahun 2012, maka anak itu diserahkan kepada negara dan disebut sebagai Anak Negara. Untuk itu si anak ditempatkan di Lembaga Pemasyarakatan

\footnotetext{
4 Lilik Mulyadi Op. cit. hlm 18

5 Bambang Waluyo, Pidana dan Pemidanaan, Sinar Grafika, Jakarta, 2008, hlm. 103

6 Bagir Manan dalam Gatot Suparmono, Hukum Acara Pengadilan Anak, Djambatan, Jakarta, 2000.hlm.40

${ }^{7}$ Ibid.hlm.29
}

Anak dan wajib mengikuti Pendidikan, pembinaan dan Latihan Kerja. Tujuannya untuk memberi bekal keterampilan kepada anak, dengan memberikan ketrampilan mengenai : Pertukangan menjalankan tindakan si anak diharapkam mampu hidup mandiri. Diserahkan kepada Departemen Sosial atau Organisasi Sosial, tindakan lain yang mungkin dijatuhkan hakim kepada anak nakal adalah menyerahkannya kepada Departemen Sosial atau Organisasi Sosial kemasyarakatan yang bergerak di bidang pendidikan, pembinaan, dan latihan kerja untuk dididik dan dibina. Walaupun pada prinsipnya pendidikan, pembinaan dan latihan kerja itu diselenggarakan oleh Pemerintah di Lembaga Pemasyarakatan Anak atau oleh Departemen Sosial. Akan tetapi dalam hal kepentingan si anak menghendaki, maka hakim dapat menetapkan anak tersebut diserahkan kepada organisasi Sosial Kemasyarakatan, seperti : pesantren, panti sosial, dan lembaga sosial lainnya Pasal 24 ayat 1 huruf c UndangUndang No. 11 Tahun 2012. Apabila anak diserahkan kepada Organisasi Sosial Kemasyarakatan, maka harus diperhatikan agama dari anak bersangkutan.

Disamping tindakan yang dikenakan kepada anak nakal, juga disertai dengan teguran dan sarat-sarat tambahan yang ditetapkan oleh kahim sesuai Pasal 24 ayat (2) Undang-Undang No. 11 Tahun 2012. Teguran itu, berupa peringatan dari hakim baik secara langsung terhadap anak, atau tidak langsung melalui orang tuanya, walinya atau orang tua asuhnya. Maksud dari teguran ini, agar anak nakal tidak lagi mengulangi perbuatan yang mengakibatkan ia dijatuhi tindakan. Sementara syarat tembahan, misalnya kewajiban untuk melapor secara periodik kepada Pembimbing Kemasyarakatan.

Hukuman yang dijatuhkan kepada anak yang melakukan tindak pidana pencurian, lebih ringan dibandingkan dengan hukuman pencurian untuk orang dewasa. Hal ini sudah sesuai dengan ketentuan perundang-undangan yang hanya menentukan pidana bagi anak adalah separo dari hukuman orang dewasa. Hukuman ini dianggap sudah cukup sebagai bentuk pendidikan bagi anak agar tidak mengulang lagi perbuatan yang sama dikemudian hari, dan tetap dapat berkembang sebagaimana anak-anak lain seusianya.

\section{Hak-hak Anak}

Islam telah mengatur hak-hak anak dalam sekumpulan hukum yang mengatur kewajiban kedua orang tuanya, masyarakat di sekitarnya dan negara. Dengan demikian hak anak bukanlah hasil kesepakatan manusia yang lemah dan serba terbatas, namun hak anak merupakan kewajiban dari Allah SWT kepada orang-orang yang harus memenuhinya. Karenanya pemenuhan hak anak adalah bagian dari ibadah atau bukti ketundukan mereka kepada Allah SWT, bukan sekedar aktivitas berdasarkan logika manusia semata atau sekedar aktivitas yang didorong oleh rasa kemanusiaan. Hak-hak anak yang harus dijamin pemenuhannya dalam Islam.

Aborsi hanya boleh dilakukan apabila kehamilan itu mengancam keselamatan nyawa ibu, sebab syara' menetapkan bahwa keselamatan ibu harus diutamakan. Adapun alasan lain untuk aborsi tidak diperbolehkan 
sama sekali. Apabila ada yang melakukan aborsi, maka negara akan mengenakan sanksi berupa qishos atau diyat atas pembunuhan jiwa yang dilakukan. Sebagaimana firman Allah SWT dalam QS Al-Baqarah ayat 178 :

Artinya:"Hai orang-orang beriman, diwajibkan atas kamu qishosh berkenaan dengan orang-orang yang dibunuh, orang merdeka dengan orang merdeka, hamba dengan hamba, dan wanita dengan wanita. Maka barangsiapa yang mendapatkan pemaafan dari saudaranya, hendaklah (yang memaafkan) mengikuti dengan cara yang baik, dan hendaklah (yang dimaafkan) membayar (diyat) kepada yang memberi maaf dengan cara yang baik"

Islam juga mengatur masalah pengasuhan anak. Anak berhak mendapatkan pengasuhan yang baik sampai ia mampu mengurus dan menjaga diri sendiri. Pengasuhan merupakan jaminan keselamatan jiwa anak dari kehancuran. Seorang anak kecil tentunya bergantung kepada orang lain ketika ia harus makan, mandi, mengganti pakaiannya, dan lain-lain. Apabila pengasuhnya tidak bisa memberinya makan dengan baik, atau tidak bisa menjaga kebersihan dirinya, atau tidak bisa menjaga keselamatan fisiknya selama masa pengasuhan, tentu jiwanya terancam. Selain itu pengasuhan yang baik juga berpengaruh pada kondisi psikis anak. Pengasuhan yang memberinya rasa tenang dan aman akan menjamin kesehatan perkembangannya jiwanya .

Islam menetapkan bahwa persoalan pengasuhan merupakan kewajiban dan sekaligus hak orang-orang tertentu. Islam pun telah menetapkan bahwa orang yang lebih berhak terhadap pengasuhan ini adalah orang yang paling dekat kekerabatannya dan paling terampil (ahli) dalam pengasuhan.

Menurut perlindungan anak dalam UndangUndang Hak Asasi Manusia tahun 1999 diatur dalam Pasal 52 sampai dengan Pasal 66, menurut Pasal 56 menjelaskan sebagai berikut :

ayat (1) setiap anak berhak untuk mengetahui siapa orang tuanya, dibesarkan, dan diasuh oleh orang tuanya sendiri."

ayat (2) dalam hal orang tua anak tidak mampu membesarkan dan memelihara anaknya dengan baik dan sesuai dengan Undang-Undang ini maka anak tersebut boleh diasuh atau diangkat sebagai anak oleh orang lain sesuai dengan ketentuan peraturan perundang-undangan."

Undang-Undang Nomor 23 Tahun 2002 tentang Perlindungan Anak dalam Pasal 14 menjelaskan sebagai berikut :

"Setiap anak berhak untuk diasuh oleh orang tuanya sendiri, kecuali jika ada alasan dan/atau hukum yang sah menunjukan bahwa pemisahan itu adalah demi kepentingan terbaik bagi anak dan merupakan pertimbangan terakhir."

Menurut Pasal 16 ayat (1) setiap anak berhak memperoleh perlindungan dari sasaran penganiayaan, penyiksaan, atau penjatuhan hukuman yang tidak manusiawi.

Menurut(Burgerlijk wetboek) Bab ke dua belas bagian ke satu tentang anak-anak sah Pasal 250 KUHPerdata sebagai berikut :

Tiap-tiap anak yang dilahirkan atau ditumbuhkan sepanjang perkawinan, memperoleh si suami sebagai bapaknya.

Pengertian anak kandung yaitu anak yang lahir dari perkawinan sah antara ayahnya dan ibunya adalah anak kandung yang sah. Ada kemungkinan dalam hidupnya ada seorang anak mengikuti ayahnya dan ibu yang melahirkannya, ada kemungkinan hanya mengikuti ibu kandungnya tanpa ayah kandung, atau mungkin juga mengikuti ayah kandungnya tanpa ibu kandung. ${ }^{8)}$

Mengatasi permasalahan perlindungan anak terlantar atau fakir miskin dalam koridor anak jalanan dengan cara mengadopsi, cara ini juga masih mempunyai kendala dalam pelindungannya, karena adanya interaksi antara fenomena yang ada dan saling mempengaruhi.

Fenomena yang relevan dalam peran perlindungan anak melalui adopsi, akan menimbulkan akibat tersendiri dan jangan sampai menimbulkan akibat dikemudian hari, untuk itu diperlukan suatu aturan perundangan yang jelas karena perlindungan anak melalui adopsi banyak ragamnya sehingga tidak menimbulkan penyimpangan negatif karena menyangkut masalah hak pewarisan.

Undang-Undang Nomor 11 tahun 2012 tentang Sistem Peradilan Anak, pada bagian umum disebutkan, terdapat pula anak yang karena satu dan lain hal tidak memperoleh kesempatan memperoleh perhatian baik secara fisik, mental maupun sosial. Karena keadaan diri yang tidak memadai tersebut, maka baik sengaja maupun tidak sengaja sering juga anak melakukan tindakan atau perilaku yang dapat merugikan dirinya dan atau masyarakat. Selain itu anak yang kurang atau tidak memperoleh kasih sayang, asuhan, bimbingan dan pembinaan dalam pengembangan sikap, perilaku, penyesuaian diri, serta pengawasan dari orang tua, wali atau orang tua asuh akan mudah terseret dalam arus pergaulan masyarakat dan lingkungannya yang kurang sehat dan merugikan perkembangan pribadinya.

Hubungan antara orang tua dengan anaknya merupakan suatu hubungan yang hakiki, baik hubungan psikologis maupun mental spritualnya. Apabila karena hubungan antara orang tua dan anak kurang baik, atau karena sifat perbuatannya sangat merugikan masyarakat sehingga perlu memisahkan anak dari orang tuannya, hendaklah tetap dipertimbangkan bahwa pemisahan tersebut semata-mata demi pertumbuhan dan perkembangan anak secara sehat dan wajar serta harus merupakan kesempatan terakhir (Ultimum Remedium).

8) Sumiarni Endang, Halim Chandra, Perlindungan Hukum Terhadap Anak dalam Hukum Keluarga, Universitas Atma Jaya Yogyakarta. hlm. 3 
Anak berhak untuk diasuh oleh orang tuanya sendiri, kecuali jika ada alasan atau aturan hukum yang sah menunjukkan bahwa pemisahan itu adalah demi kepentingan terbaik bagi anak dan merupakan pertimbangan terakhir.(Pasal 14 Undang-Undang No. 35 Tahun 2014 tentang Perlindungan Anak).

Pembuatan Undang-Undang No. 35 Tahun 2014 tentang Perlindungan Anak dilatar belakangi dengan ratifikasi Konvensi Hak Anak oleh Indonesia pada tahun 1990 setelah konvensi ini diadopsi oleh majelis umum PBB guna mengatur masalah pemenuhan hak anak. Selain itu Indonesia juga mengadopsi undang-undang tentang hak asasi manusia Undang-Undang No. 39 tahun 1999 tentang Hak Asasi Manusia. Meskipun sudah ada sejumlah undang-undang yang berkaitan dengan perlindungan anak, misalnya undang-undang kesejahteraan anak, undang-undang pengadilan anak dan lain-lain. Belum ada undang-undang yang secara utuh dapat mengatasi permasalahan anak. UndangUndang No 35 Tahun 2014 tentang Perlindungan Anak dapat dilihat sebagai salah satu produk dari Konvensi Hak Anak yang diharapkan dapat memperbaiki kondisi anak sehubungan dengan upaya pemenuhan hak anak sehingga dapat mengurangi pelanggaran hak anak baik yang dilakukan oleh orang tua dalam konteks keluarga, masyarakat maupun negara.

Pemahaman tentang anak dalam kenyataan kita dihadapkan pada perbedaan pandangan dan keyakinan yang kuat, yang berkaitan dengan masalah perlindungan anak seorang individu, kelompok organisasi swasta atau pemerintah. Hal lain berkaitan erat dengan latar belakang pendidikan, kepentingan, nilai-nilai sosial kepribadian yang bersangkutan. Jadi perlu adanya usaha mengatasi hambtan dalam masalah pengertian yang tepat mengenai anak, misalnya melalui pendidikan, penyuluhan yang meluas dan merata kepada partisipan dengan berbagai cara. Pengembangan pengertian yang tepat merupakan dasar seseorang mau ikut berpartisipasi dalam kegiatan perlindungan anak.

Keberhasilan dalam upaya perlindungan anak sedikit banyak bergantung dari kemampuan untuk membebaskan diri dari memprioritaskan kepentingan diri sendiri, kelompok, dan lembaga sehingga menjawab salah satu dari prinsip hak anak yaitu kepentingan terbaik baik bagi anak menjadi hal yang utama untuk menjadi bahan pertimbangan dalam melakukan banyak hal yang berkaitan dengan pemenuhan hak Anak.

\section{Perlindungan Anak \\ Pengertian Perlindungan}

Perlindungan anak adalah segala kegiatan untuk menjamin dan melindungi anak dan hak-haknya agar dapat hidup, tumbuh dan berkembang dan berpartisipasi secara optimal sesuai dengan harkat dan martabat kemanusian serta mendapatkan perlindungan dari kekerasan dan diskriminasi. ${ }^{9}$

Perlindungan khusus adalah perlindungan yang diberikan kepada anak dalam situasi darurat, anak yang

${ }^{9}$ Muhammad Joni dan Zulchaina Z. Tanamas, Aspek Hukum Perlindungan Anak Dalam Perspektif Konvensi Hak Anak, PT. Citra Aditya Bakti, Bandung, 1999 berhadapan dengan hukum, anak dari kelompok minoritas dan terisolasi, anak yang eksploitasi secara ekonomi dan atau seksual, anak yang diperdagangkan, anak yang menjadi penyalahgunaan narkotika, alkohol, psikotropika dan zat adiktif lainnya, anak korban penculikan, penjualan, perdagangan, anak korban kekerasan baik fisik dan jatuh mental, anak yang menyandang cacat dan anak korban perlakuan salah dan pemelaratan. ${ }^{10}$

Perlindungan bertujuan untuk menjamin terpenuhinya hak-hak anak agar dapat hidup, tumbuh dan berkembang dan berpartisipasi secara optimal sesuai dengan harkat dan martabat kemanusian serta mendapatkan perlindungan dari kekerasan dan diskriminasi demi terwujudnya anak Indonesia yang berkualitas berakhlak mulia dan sejahtera.

Pasal 17 ayat (1) Undang-Undang Nomor 35

Tahun 2014 tentang

Perlindungan Anak menyebutkan bahwa setiap anak yang dirampas kemerdekaannya (kebebasannya) berhak untuk :

a. Mendapatkan perlakuan secara manusiawi dan penempatannya dipisahkan dari orang dewasa.

b. Mendapatkan bantuan hukum atau bantuan lainnya secara efektif dalam setiap tahapan upaya hukum yang berlaku.

c. Membela diri dan memperoleh keadilan di depan pengadilan anak yang obyektif dan tidak memihak dalam sidang tertutup dan umum.

Undang-Undang Nomor 35 Tahun 2014 tentang Perlindungan Anak menyebutkan bahwa negara (pemerintah), masyarakat, keluarga dan orang tua berkewajiban dan bertanggung jawab terhadap penyelenggaraan perlindungan anak (Pasal 20 UndangUndang No. 35 Tahun 2014).

Pasal 22 Undang-Undang No. 35 Tahun 2014 menyebutkan bahwa:

Negara dan pemerintah berkewajiban dan bertanggung jawab memberikan dukungan, sarana dan prasarana dalam menyelenggarakan perlindungan anak.

Pasal 23 Undang-Undang No. 35 Tahun 2014 menyebutkan bahwa:

(1) Negara dan pemerintah menjamin perlindungan, pemeliharaan dan kesejahteraan anak dengan memperhatikan hak dan kewajiban orang tua, wali atau orang lain yang secara hukum bertanggung jawab terhadap anak.

(2) Negara dan pemerintah mengawasi penyelenggaraan perlindungan anak.

Perlu kita pikirkan bersama bahwa persoalan pemidanaan anak sangat serius karena : (1) dalam proses peradilan cenderung terjadi pelanggaran hak asasi manusia bahkan banyak bukti menunjukkan ada praktek kekerasan dan penyiksaan terhadap anak yang masuk dalam mesin peradilan, (2) perspektif anak belum mewarnai proses peradilan, (3) penjara yang menjadi tempat penghukuman anak terbukti bukan merupakan tempat yang tepat untuk membina anak mencapai proses pendewasaan yang diharapkan, (4) selama

${ }^{10}$ Bagir Manan dalam Gatot Suparmono Op.Cit., hlm.30 
proses peradilan anak yang berhadapan dengan hukum kehilangan hak-hak dasarnya seperti komunikasi dengan orang tua, hak memperoleh pendidikan, dan hak kesehatan, dan (5) ada stigma yang melekat pada anak setelah selesai proses peradilan sehingga akan menyulitkan dalam perkembangan psikis dan sosial ke depannya.

Pengertian keadilan bagi anak yang berkonflik dengan hukum adalah dipastikannya semua anak untuk memperoleh layanan dan perlindungan secara optimal dari sistem peradilan dan proses hukum. Anak berhadapan dengan hukum diartikan ketika anak dalam posisi sebagai korban, sedangkan anak berkonflik dengan hukum ketika anak diposisikan sebagai tersangka atau terdakwa pelaku tindak pidana.

Sesuai dengan esensi yang terkandung dalam tujuan Undang-Undang Pengadilan Anak yaitu 'Untuk memberikan perlindungan kepada anak dan menjamin kesejahteraan anak, meskipun ia berkonflik dengan hukum". Selain bertujuan memberikan perlindungan dan memberikan kesejahteraan kepada anak, juga bertujuan agar dalam penjatuhan sanksi hukum terhadap anak harus benar-benar secara proporsionalitas, tidak hanya memberi sanksi yang berorientasi pada penghukuman (pidana penjara) semata, akan tetapi juga memberikan alternatif lain dalam bentuk pembinaan (tredment) yaitu sanksi pidana non penal (tindakan) dengan menerapkan konsep restorative justice.

Advokasi terhadap anak sebagai bentuk upaya perlindungan anak yang sedang berkonflik dengan hukum melalui sosialisasi tentang pelaksanaan restorative justice perlu terus dilakukan dalam rangka mencari alternatif lain selain pidana penjara sebagai tujuan pemidanaan di Indonesia.

Kepolisian Republik Indonesia telah membuat pedoman dalam melaksanakan tugas sebagai penyidik Polri melalui Telegram Kapolri tertanggal 11 November 2006 dengan Nomor Pol : TR/1124/XI/2006, antara lain disebutkan; "Kategori tindak pidana yang dilakukan oleh anak yang diancam dengan sanksi pidana sampai dengan 1 tahun dapat diterapkan diversi; Kategori tindak pidana yang diancam dengan sanksi pidana di atas 1 (satu) tahun sampai dengan 5 (lima) tahun dapat dipertimbangkan untuk penerapan diversi; dan anak kurang dari 12 (duabelas) tahun dilarang untuk ditahan, dan penanganan terhadap anak yang berkonflik dengan hukum harus mengedepankan konsep restorative justice".

\section{Macam- macam Perlindungan}

Hak perlindungan yaitu perlindungan anak dari diskriminasi, tindak kekerasan dan keterlantaran bagi anak yang tidak mempunyai keluarga, dan bagi anak pengungsi. Hak perlindungan dari diskriminasi, termasuk: ${ }^{11}$

a. perlindungan anak penyandang cacat untuk memperoleh pendidikan, perwatan dan latihan khusus, dan

b. hak anak dari kelompok masyarakat minoritas dan penduduk asli dalam kehidupan masyarakat negara.

Perlindungan dari ekploitasi, meliputi a. perlindungan dari gangguan kehidupan pribadi,

b. perlindungan dari keterlibatan dalam pekerjaan yang mengancam kesehatan, pendidikan dan perkembangan anak,

c. perlindungan dari penyalahgunaan obat bius dan narkoba, perlindungan dari upaya penganiayaan seksual, prostitusi, dan pornografi,

d. perlindungan upaya penjualan, penyelundupan dan penculikan anak,

e. perlindungan dari proses hukum bagi anak yang didakwa atau diputus telah melakukan pelanggaran hukum.

\section{HASIL DAN PEMBAHASAN \\ Faktor yang mempengaruhi anak di Kelurahan Cigending Kecamatan Ujung Berungmengkonsumsiminuman keras}

Seperti yang kita ketahui bersama pesta miras selain mebawa efek yang buruk bagi pelakunya, perilaku ini juga membawa efek negatif bagi warga yang tidak langsung terlibat di dalamnya. Contohnya dapat dilihat dari beberapa peristiwa kejahatan yang terjadi setelah orang meminum-minuman keras. Seperti premanisme yang terjadi di jalanan dimana sering terjadinya pemerasan terhadap warga setelah beberapa orang berpesta miras. Alkohol yang merupakan bahan yang terkandung dalam minuman keras memberikan efek tertentu sehingga peminumnya tidak dapat mengontrol perilakunya dengan benar. Banyaknya peristiwa pesta miras di masyarakat ini tentunya didukung oleh beberapa faktor.Banyaknya pesta miras ini tentunya terjadi tidak begitu saja, kemudahan masyarakat Kelurahan Cigending mendapatkan minuman keras membuat beberapa orang dengan mudahnya berpesta miras. Kalau kita melihat beberapa peristiwa, pesta miras ini dilakukan oleh sekelompok orang sudah berusia tua sampai anak SMU yang usianya baru belasan tahun. Hal ini terjadi karena orang-orang dapat membeli minuman keras dengan mudah di toko-toko minimarket.

Produk minuman keras seperti bir dengan kadar alkohol di bawah $5 \%$ oleh pemerintah diperbolehkan untuk dijual bebas di minimarket-minimarket yang notabenenya dekat dengan lingkungan perumahan. Lalu timbul permasalahan sulitnya pranata sosial melakukan pengawasan karena lokasi minimarket yang tersebar dimana-mana dan membuat masyarakat dapat meminumnya dimana saja. Belum lagi ditambah banyaknya kios-kios minuman illegal yang banyak muncul di beberapa pemukiman masyarakat. Tempat penjualan semi permanen bahkan menjual minuman yang kadarnya lebih tinggi bahkan sampai di atas 55\%. Kemudahan akses terhadap minuman keras ini kemudian menjadi salah satu faktor pendukung banyaknya peristiwa pesta miras di masyarakat.

Faktor pendukung lainnya dari maraknya pesta miras di masyarakat Kelurahan Cigending adalah beredarnya miras ilegal di masyarakat. Minuman keras yang diperbolehkan untuk dijual oleh pemerintah adalah minuman yang berkadar paling tinggi 55\% dan dalam peredarannya diatur oleh peraturan pemerintah. Hal ini menginsyaratkan bahwa pemerintah sudah mengatur sebuah mekanisme kontrol terhadap peredaran 
minuman keras sesuai dengan kadarnya sehingga efek dari minuman tersebut juga dapat dikontrol. Namun apa yang terjadi apabila minuman keras yang beredar di Indonesia tidak hanya minuman keras yang legal. Banyak minuman keras yang beredar di Indonesia tidak memenuhi peraturan yang diisyaratkan dalam UndangUndang dimana minuman tersebut masuk ke Indonesia secara ilegal atau malah dibuat di dalam negeri secara ilegal. Minuman yang dibuat di dalam negeri secara ilegal contohnya seperti cap tikus, arak putih, ciyu dan lain-lain. Pembuatan yang ilegal tentu saja membuat produk tersebut tidak memungkinkan dijual secara legal, untuk itu biasanya minuman keras jenis ini dijual di kioskios minuman keras atau jamu yang keberadaannya tidak mengantongi izin dari pemerintah. Hal ini tentunya membuat pengawasan oleh pemerintah menjadi semakin sulit untuk dilakukan. Dan minimnya pengawasan membuat pemerintah sulit untuk mengontrol efek negatif yang ditimbulkan.

Faktor yang ketiga adalah kurang seriusnya perhatian pemerintah terhadap masalah minuman keras yang ditunjukkan dengan kurang ketatnya kebijakan publik pemerintah yang mengatur masalah minuman keras. Polisi sebagai penegak hukum hanya bisa menertibkan tindak pidana yang melanggar hukum positif yang sudah diatur dalm undang-undang. Beberapa permasalah yang terjadi adalah polisi kesulitan menindak penjual minuman yang berjualan sembarangan di lingkungan pemukiman warga Kelurahan Cigending. Walaupun penjualan minuman keras di lingkungan pemukiman itu dirasa tidak pantas secara nilai sosial karena akan memberikan pengaruh negatif kepada anak-anak, namun hal ini tidak diatur dalam pelanggaran pidana melainkan hanya termasuk dalam kategori pelanggaran. Sehingga ketika menemukan kios-kios minuman keras di sekitar pemukiman, polisi tidak dapat melakukan apa-apa selain menunggu orang yang meminum minuman keras tersebut melakukan tindak pidana kemudian menangkapnya. Apabila pemerintah menaruh perhatian serius kepada permasalahan ini seharusnya pemerintah merumuskan kebijakan publik yang sesuai untuk kemudian diterapkan dalam bentuk undang-undang sehingga bisa dilakukan penindakan oleh kepolisian.

Faktor berikutnya penyebab maraknya pesta miras adalah kurangnya kinerja aparat dalam melakukan langkah-langkah penanganan sistematis terhadap masalah publik ini. Tindakan aparat terkait pengontrolan peredaran dan penjualan minuman keras dapat digolongkan masih rendah. Tindakan razia yang nyatanyata dirasa dapat menekan peredaran minuman keras ilegal dan pesta miras biasanya hanya dilakukan menjelang bulan ramadhan saja dan sangat jarang dilakukan di bulan lainnya. Dan akhirnya masyarakatpun menganggap wajar kalau pesta miras masih marak terjadi dikarenakan Polri kurang maksimal dalam melaksanakan tugasnya

Peredaran minuman keras di Kelurahan Cigending sangat sulit apabila harus dibasmi/dihilangkan sama sekali. Mungkin dari sisi agama masalah miras tidak ada toleransi, namun kita perlu juga melihatnya dari sisi lain yaitu kepentingan adat dan kepentingan Pariwisata. Dengan demikian yang penting bukan membasmi miras, tapi memperhatikan perangkat hukum untuk mengaturnya dan kemudian menegakkan peraturannya. Peredaran minuman keras sangat perlu adanya larangan dalam Peraturan Daerah. Kendatipun dalam KUHP khususnya Pasal 536, 537, 538 dan 539 secara eksplisit sudah mengatur tentang miras ini, namun kelihatannya pasal-pasal tersebut perlu direvisi kembali karena banyak yang kurang tegas dan kurang mengenai substansi (masih sumir) tentang miras itu sendiri, sehingga menyulitkan aparat keamanan untuk mengambil tindakkan tegas.

Penjualan miras seharusnya diberikan ijin di tempat-tempat tertentu seperti hotel, diskotek, karaoke dan took khusus penjual miras harus diatur oleh Peraturan Daerah dan selanjutnya dimplementasikan sampai ketingkat Kelurahan dikarenakan peredaran minuman keras dimungkinkan terjadi di masyarakat terkecil seoerti yang terjadi di Kelurahan Cigending Kecamatan Ujung Berung Kota Bandung. Izin untuk menjadi distributor, pengedar dan penampung miras harus ketat. Artinya agar mereka tidak terlalu gampang melakukan bisnis miras dengan tanpa melihat usia konsumennya.

Penyalah gunaan terhadap izin dan Peraturan Daerah setempat tentang miras ini harus ditindak tegas dengan cara menghukum pelakunya, bukan memusnahkan mirasnya. Razia rutin harus dilakukan untuk mengontrol apakah para distributor, penjual dan penampung tetap konsisten pada peraturan yang ada dan sesuai dengan izin yang diberikan kepada mereka. Dalam hal penanggulangan miras ini kita perlu memperhatikan dua hal : pemerintah daerah juga menerima pemasukkan dari persediaan miras dari wisatawan asing harus ada yaitu di hotel-hotel berbintang, restoran, diskotek, club malam lainnya. Namun kebijakkan ini harus disertai dengan perangkat hukum yang jelas dan tegas, agar tidak disalah gunakan dikemudian hari.Hal ini perlu segera dipertegas legalisasinya dengan Undang- Undang atau peraturan Daerah, agar penggunaan miras pada saat acara adapt betul-betul disiplin hanya untuk keperluan acara adapat dan bukan untuk acara mabuk- mabukan atau kompetensi antara anak-anak muda.

Salah satu prilaku anak yang menginjak usia remaja yaitu ingin menampilkan jati dirinya kepada teman atau lingkungan, dengan perilaku lingkungan yang kurang baik dan tidak diperhatikan dengan baik oleh keluarga bisa kebablasan. Bisa jadi terjerumus ke dalam lingkungan yang tidak baik, apalagi orang tua kurang menanamkan ilmu agama kepada anak sejak dini hingga remaja.Secara umum remaja ingin diakui keberadaannya dan mendapat perlakuan khusus. Untuk menunjukkannya, perilaku remaja terkadang mengarah pada bentuk mencari perhatian, dengan menonjolkan dirinya dalam perbuatan negatif, salah satunya adalah mengkonsumsi minuman keras.

Pergaulan yang negatif yang memberikan pengaruh dalam penggunaan minuman keras dikalangan remaja Kelurahan Cigending Kecamatan Ujung Berung Kota Bandung. Karena dengan minumminuman keras mereka berharap bisa mendapatkan kegembiraan, menghilangkan rasa rendah diri, mempertahankan gengsi. Di samping itu, tidak sedikit 
remaja yang ikut-ikutan dan hanya sekedar mencari perhatiaan dan pengakuan bahwa dialah yang paling hebat.

Anak yang mencoba-coba biasanya jadi terjebak atau kecanduan minuman keras karena merasa bosan, butuh tantangan, atau ingin memberontak. Hal ini tentu tak akan terjadi kalau dalam hidupnya anak memiliki minat dan kesibukan di bidang lain. Waktu dan pikirannya akan tersita oleh hal-hal yang positif dan membangun. Maka, pastikan orang tua menggali dan mengembangkan minat dan bakatnya. Misalnya anak suka bermain musik, bermain sepak bola, atau mengotak-atik komputer.Salah satu caranya adalah dengan mengenal orangtua teman anak. Cara lainnya adalah mengajak anak mengobrol soal temantemannya. Jangan lupa tegaskan dari awal kalau pertemanan harus saling membangun dan mendukung, bukannya malah jadi pengaruh negatif.Sebenarnya, tingkat pengetahuan masyarakat tentang bahaya minuman keras sudah cukup baik, hanya saja pemahaman tentang bagaimana upaya pencegahan narkoba masih tergolong rendah. Dengan demikian, perlu adanya upaya komunikasi, edukasi, dan informasi yang lebih maksimal tentang cara melakukan pencegahan efektif dari ancaman bahaya narkoba. Dalam hal ini, peran orang tua memiliki andil sangat besar dalam melindungi anak-anak dari ancaman barang haram dan berbahaya tersebut.

\section{Upaya pencegahan anak dari pengaruh buruk minuman keras di Kelurahan Cigending Kecamatan Ujung Berung ditinjau dari Undang-Undang No 35 Tahun 2014 TentangPerlindungan anak}

Upaya mengawasi penjualan miras dan bahanbahan atau zat kimia yang dijual di apotek atau toko kimia yang rawan disalahgunakan. Khususnya, yang digunakan sebagai campuran miras oplosan. Kedua, langkah preventif di antaranya dengan melakukan razia ke sekolah-sekolah. Petugas melakukan pemeriksaan terhadap barang-barang yang dibawa para siswa ke sekolah. Hal ini untuk mengantisipasi siswa membawa miras, narkoba, senjata api (senpi) maupun senjata tajam (sajam). Untuk membantu polisi di sekolahsekolah telah dibentuk polisi siswa (polsis). Cara ketiga yakni refresif berupa operasi penindakan dan penertiban. Sasarannya adalah warung, kafe, maupun toko jamu yang diduga menjual miras dan oplosan. Polisi juga berupaya merekrut jaringan informasi sebagai bagian operasi intelijen mengungkap peredaran miras. Tindakan ini dilakukan karena peredaran miras dan oplosan saat ini sudah meniru peredaran dan transaksi narkoba.

Penjual dan pembeli miras tidak bertemu langsung melainkan memesan melalui sambungan telpon atau media teknologi informasi lainnya. Di samping ketiga cara tersebut, polisi dan elemen masyarakat lainnya menggelar deklarasi anti peredaran miras. Langkah tersebut untuk memperkuat komitmen dalam menanggulangi masalah miras. Polisi harus mengerahkan Bintara Pembina Keamanan Ketertiban Masyarakat (Babinkamtibmas) untuk terjun ke masyarakat dalam program door to door. Kegiatan ini untuk memberikan sosialisasi mengenai bahaya miras hingga tingkat masyarakat di desa hingga rukun tetangga (RT) maupun rukun warga (RW). Dalam kesempatan tersebut petugas Babinkamtibmas akan meminta orangtua untuk mengawasi anak-anaknya agar terhindari dari miras maupun narkoba. Harapannya, orangtua memberikan perhatian yang cukup kepada anak-anak.

Setiap orang tua tentu menginginkan putra dan putrinya tumbuh jadi orang yang bertanggung jawab dan bijak dalam mengambil pilihan. Namun, sekarang banyak anak dan remaja yang mulai mencoba narkoba, minuman keras, dan rokok. Sekadar melarang anak saja tidak cukup untuk menjauhinya dari hal-hal berbahaya tersebut. Kebanyakan anak dan remaja yang mencobacoba biasanya mengikuti jejak orangtuanya. Maka, jangan merokok atau mabuk di hadapan anak. Lebih baik lagi kalau berhenti merokok sama sekali. Ingat, tak ada pesan yang lebih kuat bagi anak daripada tindakan ibu dan ayahnya sendiri.Cara ampuh untuk mencegah pengaruh-pengaruh buruk dalam hidup anak adalah dengan mengenal anak lebih dalam. Kebanyakan orangtua yang anaknya menggunakan narkoba, merokok, atau minum merasa sudah cukup mengenal anaknya sendiri ketika tiba-tiba menangkap basah anaknya mabuk atau merokok. Untuk menghindarinya, rutinlah berkomunikasi dengan anak. Ajak anak mengobrol soal topik apapun sehingga ia lebih terbuka pada orang tua. Tanyakan apakah anak pernah ditawari rokok, minuman keras, atau obatobatan. Tanya juga apa pendapat anak soal orangorang yang merokok dan sering mabuk.

Hal terbaik yang bisa dilakukan orang tua untuk mencegah penyalahgunaan narkoba, alkohol termasuk rokok pada anak-anak adalah dengan cara melakukan komunikasi sejak dini pada sang anak. Bicarakan dengan anak-anak tentang bagaimana zat ini berbahaya bagi mereka. Jelaskan efeknya bagi tubuh, psikologis, bahkan masa depannya. Diskusikan pada buah hati, bagaimana cara mengambil keputusan yang bertanggung jawab tanpa terpengaruh dari perilaku teman sebaya.Jangan lupa untuk memuji prestasi yang dilakukan anak agar membangun harga dirinya. Biarkan mereka aktif terlibat dalam kegiatan positif seperti olahraga, seni lukis, dan kegiatan lain yang disukainya. Selain itu selalu luangkan waktu bersama anak, untuk sekedar bicara dan mengetahui kegiatannya seharian.

Perlindungan (advokasi) terhadap anak secara yuridis merupakan upaya yang ditujukan untuk mencegah agar anak tidak mengalami perlakuan yang diskriminatif/perlakuan salah (child abused) baik secara langsung maupun tidak langsung dalam rangka menjamin kelangsungan hidup, tumbuh dan perkembangan anak secara wajar, baik fisik maupun mental dan sosial.

Kelangsungan hidup dan perkembangan anak serta kehidupan sosial dan penghargaan terhadap pendapat anak yang berkonflik dengan hukum merupakan permasalahan yang sangat kompleks, dan banyak faktor yang menyebabkan anak terlibat dalam konflik hukum. Baik sebagai korban maupun sebagai pelaku, anak yang berkonflik dengan hukum memerlukan perlindungan mengingat anak adalah individu yang masih belum matang dan masih sangat 
tergantung pada orang lain. Pada hakikatnya anak tidak dapat melindungi diri sendiri terhadap berbagai ancaman mental, fisik, sosial dalam berbagai bidang hidup, kehidupan dan penghidupan, khususnya dalam pelaksanaan peradilan pidana anak yang masih asing bagi dirinya.

Perlakuan bagi anak yang berorientasi terhadap perlindungan serta pemenuhan hak-hak bagi anak sudah merupakan suatu kewajiban bagi seluruh komponen bangsa terutama para aparat penegak hukum sebagaimana telah diamanatkan oleh Undang Undang Nomor 11 Tahun 2012 Tentang Sistem Peradilan Anak dan Undang Undang Nomor 35 Tahun 2014 Tentang Perlindungan Anak. Undang-undang tersebut merupakan jaminan pelaksanaan hak-hak anak di bidang hukum. Sudah jamak diketahui bahwa permasalahan perlindungan anak di Indonesia sangat berat dan kompleks. Salah satu persoalan yang serius dan mendesak untuk memperoleh perhatian adalah penanganan anak yang berhadapan dengan hukum atau anak yang berkonflik dengan hukum $(\mathrm{ABH})$.

Salah satu upaya yang dapat dilakukan Polri wilayah terdekat yaitu Polsek Ujung Berung untuk menekan angka kejadian pesta miras yang terjadi di masyarakat Kelurahan Cigending adalah dengan melakukan razia terhadap miras ilegal. Tugas penertiban ini sesuai dengan yang diamanatkan oleh UndangUndang Pangan dimana Polri berhak dan wajib untuk menertibkan miras ilegal tanpa izin yang sesuai dengan peraturan perundang-undangan yang berlaku. Upaya penertiban miras ilegal ini akan sangat berpengaruh terhadap penurunan angka kejadian pesta miras karena menurut beberapa kejadian yang terjadi, warga yang melakukan pesta miras biasanya dari golongan ekonomi menengah ke bawah yang mengkonsumsi miras lokal ilegal seperti cap tikus, ciyu, bir pletok, dan lain-lain. Polsek Ujung Berung sangat perlu menertibkan miras ilegal ini karena di dalam miras ilegal ini kadar alkoholnya tergolong tinggi dan tidak sesuai dengan standar yang ditetapkan oleh pemerintah. Dengan kadar alkohol yang tinggi tentunya akan menimbulkan efek yang tidak terkontrol pula bagi peminumnya. Dengan adanya upaya penertiban miras ilegal ini, diharapkan kejadian pesta miras akan menurun karena minuman yang biasa digunakan untuk pesta miras tidak ada lagi di pasaran.

Melakukan penertiban terhadap penjual miras yang tidak sesuai dengan aturan. Selain meminum minuman keras yang ilegal, pesta miras biasanya dilakukan di tempat-tempat umum seperti di pinggir jalan, lapangan atau gardu yang lokasinya berdekatan dengan kios penjual minuman keras tak berizin. Penjual miras tak berizin ini mempunyai kontribusi yang tinggi dalam kejadian pesta miras karena pemerintah selaku pranata sosial tidak dapat mengontrol penjualan barang yang ada di kiosnya, berbeda dengan minimarket atau toko-toko berizin yang secara berkala melaporkan penjualannya kepada pemerintah. Selain itu posisi kios penjual miras tak berizin yang biasanya dekat dengan pemukiman atau tempat berkumpulnya masyarakat ini dapat juga menjadi stimultan bagi orang yang lewat di sekitarnya. Kehadiran kios-kios tidak berizin ini membuat orang yang tidak ada niat meminum alkohol menjadi tertarik untuk meminum alkohol setelah melihatnya. Melihat besarnya dorongan yang ditimbulkan oleh penjual miras tak berizin ini, sudah tepat apabila Polri melakukan pebertiban terhadap penjual miras yang tidak sesuai dengan aturan sehingga dapat menekan angka kejadian pesta miras di masyarakat di Kelurahan Cigending.

Polsek Ujung Berung hanya dapat menegakkan hukum apabila hukum itu sendiri sudah diciptakan oleh pemerintah. Terkadang timbul juga kendala yang dialami Polsek Ujung Berung saat melakukan penertiban yaitu tidak adanya aturan yang mengatur sehingga Polsek Ujung Berung tidak dapat melakukan penertiban dengan maksimal. Untuk itu perlu adanya feedback dari Polsek Ujung Berung kepada pemerintah yang bertugas untuk membuat kebijakan publik dalam bentuk peraturan perundang-undangan sehingga masalah publik dapat ditangani dengan baik. Penyempurnaan kebijakan publik ini merupakan sebuah proses yang wajar dan selazimnya ada untuk memperoleh sebuah formula kebijakan publik yang ideal bagi masyarakat. Dalam hal ini adalah kebijakan publik yang mengatur mengenai minuman keras sehingga masalah publik seperti pesta miras ini dapat diatasi.

Polsek Ujung Berung berupaya mendorong warga untuk tidak meminum minuman keras juga dapat mencegah generasi muda yang belum pernah mencoba minuman keras untuk tidak melakukannya. Hal ini kemudian dapat membentuk budaya anti miras di lingkungan masyarakat. Ketika budaya anti miras sudah terbentuk maka upaya kontrol sosial dapat dilakukan tidak hanya oleh Polsek Ujung Berung tapi juga oleh masyarakat.

\section{SIMPULAN}

Banyaknya pesta miras ini tentunya terjadi tidak begitu saja, kemudahan masyarakat Kelurahan Cigending mendapatkan minuman keras membuat beberapa orang dengan mudahnya berpesta miras. Kalau kita melihat beberapa peristiwa, pesta miras ini dilakukan oleh sekelompok orang sudah berusia tua sampai anak SMU yang usianya baru belasan tahun. Hal ini terjadi karena orang-orang dapat membeli minuman keras dengan mudah di toko-toko minimarket. Kemudahan akses terhadap minuman keras ini kemudian menjadi salah satu faktor pendukung banyaknya peristiwa pesta miras di masyarakat.Faktor pendukung lainnya dari maraknya pesta miras di masyarakat Kelurahan Cigending adalah beredarnya miras ilegal di masyarakat. Salah satu prilaku anak yang menginjak usia remaja yaitu ingin menampilkan jati dirinya kepada teman atau lingkungan, dengan perilaku lingkungan yang kurang baik dan tidak diperhatikan dengan baik oleh keluarga bisa kebablasan. Secara umum remaja ingin diakui keberadaannya dan mendapat perlakuan khusus.Pergaulan yang negatif yang memberikan pengaruh dalam penggunaan minuman keras dikalangan remaja Kelurahan Cigending Kecamatan Ujung Berung Kota Bandung. Karena dengan minum-minuman keras mereka berharap bisa mendapatkan kegembiraan, menghilangkan rasa rendah diri, mempertahankan gengsi. Di samping itu, tidak sedikit remaja yang ikut-ikutan dan hanya sekedar 
mencari perhatiaan dan pengakuan bahwa dialah yang paling hebat

Minuman keras dapat merusak perkembangan tumbuh kembang anak sehingga perlu adanya upaya untuk melindungi anak dari pengaruh buruk miniman keras sebagai upaya penerapan Undang-Undang Nomor 35 Tahun 2014 Tentang Perlindungan Anak. Tugas penertiban ini sesuai dengan yang diamanatkan oleh Undang-Undang Pangan dimana Polri berhak dan wajib untuk menertibkan miras ilegal tanpa izin yang sesuai dengan peraturan perundang-undangan yang berlaku. Upaya penertiban miras ilegal ini akan sangat berpengaruh terhadap penurunan angka kejadian pesta miras karena menurut beberapa kejadian yang terjadi, warga yang melakukan pesta miras biasanya dari golongan ekonomi menengah ke bawah

\section{DAFTAR PUSTAKA}

Arief Gosita, Pengembangan Hak-Hak Anak Indonesia Dalam Proses Peradilan Pidana. Rajawali. Jakarta 1986.

-"Beberapa Permasalahan Pelaksanaan Perlindungan anak", Makalah dalam Seminar Nasional Perlindungan Anak, Jakarta, 1982.

Bambang Waluyo, Pidana dan Pemidanaan,Sinar Grafika, Jakarta, 2008,

Gatot Suparmono,Hukum Acara Pengadilan Anak, Djambatan, Jakarta, 2000.

Lilik Mulyadi, Pengadilan Anak di Indonesia Teori, Praktik dan Permasalahannya, Mandar Maju, Bandung 2005,

Muhammad Joni dan Zulchaina Z. Tanamas, Aspek Hukum Perlindungan Anak Dalam Perspektif Konvensi Hak Anak, PT. Citra Aditya Bakti, Bandung, 1999

Sumiarni Endang, Halim Chandra, Perlindungan Hukum Terhadap Anak dalam Hukum Keluarga, UniversitasAtma Jaya Yogyakarta.

Undang-Undang No. 2 Tahun 2002 Tentang Kepolisian

Undang-Undang No. 11 tahun 2012 Tentang sistem Peradilan Anak

Undang-Undang No 35 tahun 2014 tentang Perlindungan Anak 